\title{
Yangjing Capsule Extract Promotes Proliferation of GC-1 Spg Cells
}

\author{
Zhiqiang Wang, ${ }^{1}$ Baofang Jin, ${ }^{1}$ Xindong Zhang, ${ }^{1}$ Yugui Cui, ${ }^{2}$ Dalin Sun, ${ }^{1}$ and Chao Gao \\ ${ }^{1}$ Institute of Andrology, Nanjing University of Chinese Medicine, No. 138 Xianlin Road, Nanjing, Jiangsu 210023, China \\ ${ }^{2}$ State Key Laboratory of Reproductive Medicine, Clinical Center of Reproductive Medicine, First Affiliated Hospital, \\ Nanjing Medical University, Nanjing 210029, China
}

Correspondence should be addressed to Baofang Jin; hexiking@126.com

Received 8 January 2014; Revised 20 March 2014; Accepted 24 March 2014; Published 10 April 2014

Academic Editor: Yuping Tang

Copyright (C) 2014 Zhiqiang Wang et al. This is an open access article distributed under the Creative Commons Attribution License, which permits unrestricted use, distribution, and reproduction in any medium, provided the original work is properly cited.

\begin{abstract}
Objective. To investigate the effect of Yangjing Capsule (YC) extract on proliferation of GC-1 spermatogonia (spg) cells and the mechanism. Methods. GC-1 spg cells were treated with $0.01,0.1$, and $1 \mathrm{mg} / \mathrm{mL}$ YC extract. MTT assay was performed to detect the cell viability. Flow cytometry was used to measure the cell cycle and apoptosis of GC-1 spg cells. Real-time PCR and western blot were applied to determine the mRNA and protein expression of Oct-4 and Plzf. Gfr $\alpha 1$ knockdown and LY294002 (PI3K inhibitor) were applied to explore the underlying mechanism. Results. After $48 \mathrm{~h}$ treatment of YC, the viability of GC-1 spg cells increased significantly and the ratio of apoptotic cells reduced significantly. The increased mRNA and protein expression of Oct- 4 and Plzf suggested YC promoted self-renewal of GC-1 spg cells. Both Gfr $\alpha 1$ siRNAs and LY294002 treatments held back YC extract's stimulation effects on mRNA and protein expression of Oct-4 and Plzf and consequently inhibited the proliferation of GC-1 spg cells induced by YC extract. Conclusion. YC extract could stimulate the proliferation of GC-1 spg cells. Partly via Gfr $\alpha 1$, YC extract is able to trigger the activation of PI3K pathway and finally lead to self-renewal of GC-1 spg cells.
\end{abstract}

\section{Introduction}

About $15 \%$ of couples have problems in conceiving [1] and infertility beset around 80 million people worldwide by causing considerable psychological and financial burden. It is estimated that male reproductive dysfunction contributes to about half of infertile couples [2,3]. Male infertility could be caused by various reasons, for instance, failure in spermatogenesis, epididymal maturation or storage of sperm, abnormal sperm delivery or accessory gland function, genetic or environmental factors, and sexual disorders $[4,5]$. Among these causes, defects in spermatogenesis are the most common and account for $20 \%-25 \%$ of cases [6].

Spermatogenesis occurs in the seminiferous tubules of the testis with the seminiferous epithelium containing the developing germ cells and somatic Sertoli cells. Spermatogenesis is a continuous process by which the haploid germ cells are produced from differentiation of spermatogonial stem cells (SSCs) through mitosis and meiosis [7]. SSCs are responsible for sustaining fertility by tightly balancing between self-renewal and differentiation. With the establishment of balance, sperms are produced continually throughout the lifespan of an adult male [8-10]. Increased differentiation of SSCs at cost of self-renewal which destroys the balance would lead to male sterility [6]. Oct- 4 and Plzf are considered to be responsible for preserving the pluripotency and self-renewal of stem cells $[11,12]$. They are generally accepted as stem cell markers as they are downregulated during differentiation.

Self-renewal and differentiation of SSCs are strictly regulated by a combination of extrinsic gene signals from the niche as well as intrinsic signal pathways. Glial cell linederived neurotrophic factor (Gdnf), secreted by Sertoli cells, is specifically responsible for the maintenance and self-renewal of SSCs $[13,14]$. By binding to glycosylphosphatidylinositol- (GPI-) anchored cell surface molecule (Gfr $\alpha 1$ ), Gdnf is able to trigger PI3K/AKT pathway and eventually lead to self-renewal of SSCs $[15,16]$. It has already been demonstrated that abnormal expression of extrinsic or intrinsic signaling molecules can give rise to impaired spermatogenesis $[17,18]$. Oligozoospermia, asthenozoospermia, 
teratozoospermia, and azoospermia are the most common clinical manifestation of male infertility resulting from impaired spermatogenesis. In these cases, signal pathways regulating SSCs, such as PI3K/AKT pathway [19], are likely to be disrupted, thereby self-renewal of SSCs decreased and male infertility occurred.

The Yangjing Capsule (YC), which is composed of Herba Epimedii Brevicornus, Placenta Hominis, Rhizoma Polygonati Sibirici, Radix Rehmanniae Preparata, Angelica sinensis, and other components, has been suggested for the treatment of diseases of the reproductive system [20, 21]. Our previous clinical study found that $\mathrm{YC}$ was very effective for oligospermatism and can markedly increase sperm density for patients with a sperm density of over $5 \times 10^{6} / \mathrm{mL}$ [22]. While medical practice has proved the efficacy of Chinese herbal formulation, the underlying molecular mechanisms of YC improving male fertility remain elusive. Our present study is aimed to determine whether YC could promote selfrenewal of SSCs and explore the targeted signal pathways involved.

\section{Materials and Methods}

2.1. Chemicals. Dulbecco's modified eagle's medium (DMEM), fetal bovine serum (FBS), and lyophilized trypsinEDTA were obtained from GIBCO BRL (Grand Island, NY, USA). 3-[4,5-Dimethylthiazolyl-2]-2,5-diphenyltetrazolium bromide (MTT), dimethyl sulfoxide (DMSO), sodium dodecyl sulfate (SDS), and Tris/ $\mathrm{HCl}$ were purchased from Sigma (St. Louis, MO, USA). The whole protein extraction kits were purchased from Keygen (Keygen Biotech. Co. Ltd., Nanjing, China). Trizol reagent, PrimeScript RT Master Mix, and SYBR Green PCR Master Mix reagent kits were obtained from TaKaRa (TaKaRa Biotechnology, Dalian, China). The primers were synthesized by Invitrogen Life Tech (Carlsbad, CA, USA). Rabbit monoclonal anti-AKT (phospho S473), rabbit polyclonal anti-Plzf ab38739, and anti-Oct-4 ab18976 were from Abcam (Cambridge, MA, USA). Mouse monoclonal anti- $\beta$-actin was from Chemicon (Temecula, CA). Enhanced chemiluminescence was obtained from Amersham Biosciences (Uppsala, Sweden).

2.2. Preparation of YC Extract. The YC is composed of 11 traditional Chinese drugs: 13.3\% Yinyanghuo (Herba Epimedii Brevicornus), 13.3\% Muli (Concha Ostreae (calcined)), 13.3\% Wangbuliuxing (Semen Vaccariae Segetalis), 10\% Huangqi (Radix Astragali Mongolici), 10\% Danggui (Radix Angelicae Sinensis), 6.7\% Huangjing (Rhizoma Polygonati Sibirici), 6.7\% Shayuanzi (Semen Astragali Complanati), 6.7\% Ziheche (Placenta Hominis), 6.7\% Shudihuang (Radix Rehmanniae Preparata), 6.7\% Lizhihe (Semen Litchi), and 6.7\% Shuizhi (Hirudo). The YC extract was prepared based on the methods described by Kao et al. [23]. The content of the YC (equivalent to $10 \mathrm{~g}$ of crude drug) was extracted with distilled water and subsequently subjected to ultrasonic extraction for $45 \mathrm{~min}$. The supernatant was collected and centrifuged at $13,000 \mathrm{~g}$ and $4^{\circ} \mathrm{C}$ for $30 \mathrm{~min}$ to collect the supernatant, which was concentrated to $100 \mathrm{~mL}$ with a rotary evaporator at $60^{\circ} \mathrm{C}$. The final concentration of the YC extract corresponded to
$100 \mathrm{mg} / \mathrm{mL}$ of the crude herbal dose. The $\mathrm{pH}$ of the extract was adjusted to 7.0, and the extract was sterilized by filtration and stored at $-80^{\circ} \mathrm{C}$ until use.

2.3. siRNA Transfection and PI3K Inhibition of GC-1 Spg Cells. GC-1 spg cells were cultured in DMEM, supplemented with $10 \% \mathrm{FBS}, 50 \mathrm{IU} / \mathrm{mL}$ penicillin, and $50 \mu \mathrm{g} / \mathrm{mL}$ streptomycin, and then incubated in a $5 \% \mathrm{CO}_{2}$ incubator (Thermo Fisher Scientific, Rochester, USA) at $37^{\circ} \mathrm{C}$. For determining effects of YC extract on the self-renewal, GC-1 spg cells were treated with $0,0.01,0.1$, and $1 \mathrm{mg} / \mathrm{mL}$ YC extract and $20 \mathrm{ng} / \mathrm{mL}$ Gdnf (used as positive control), respectively. After $48 \mathrm{~h}$, cells were collected for assay of proliferation, cell cycle, and apoptosis. RNAs and protein were prepared to detect the expression of Plzf and Oct- 4 by quantitative PCR and western blot. To explore the underlying mechanism, Gfr $\alpha 1$ knockdown and PI3K inhibition were performed. For Gfr $\alpha 1$ knockdown, 19-nucleotide siRNA sequences (sense: $5^{\prime}$-GCC CUC ACA GGC UUC UGU U-3' and antisense: $3^{\prime}$-CGG GAG UGU CCG AAG ACA A-5') targeting mouse Gfr $\alpha 1$ sequence (GCC CTC ACA GGC TTC TGT T) were designed using BLOCK-iT RNAi Designer (Invitrogen) and synthesized by Invitrogen [24]. The Stealth RNAi negative control obtained from Invitrogen was used as a control for monitoring nonsequence-specific effects. 50 pmol Stealth RNAi negative control and Gfr $\alpha 1$ siRNA were transfected into GC-1 spg cells using Lipofectamine 2000 (Invitrogen) according to the manufacturer's instruction. At $48 \mathrm{~h}$ after transfection, cells were treated with $1 \mathrm{mg} / \mathrm{mL}$ YC extract for $48 \mathrm{~h}$ and collected for proliferation assay, quantitative PCR, and western blot. For PI3K inhibition, GC-1 spg cells were exposed by $50 \mu \mathrm{M}$ LY294002 (targeting the ATP-binding site of the PI3K) for abrogating PI3K activation. $2 \mathrm{~h}$ later, $1 \mathrm{mg} / \mathrm{mL}$ YC extract was added and cells were collected for proliferation assay, quantitative PCR, and western blot.

2.4. MTT Assay of Cell Proliferation. Cells were seeded in 96well plate for $48 \mathrm{~h}$ treatment of $0,0.01,0.1$, and $1 \mathrm{mg} / \mathrm{mL} \mathrm{YC}$ extract, $20 \mathrm{ng} / \mathrm{mL}$ Gdnf, $50 \mu \mathrm{M}$ LY294002, and $50 \mathrm{pmol}$ Gfr $\alpha 1$ siRNA, respectively $(n=5)$. MTT $(5 \mathrm{mg} / \mathrm{mL})$ was added with $20 \mu \mathrm{L}$ to each well and incubated for another $4 \mathrm{~h}$ before it was discarded. Then the purple-blue MTT formazan precipitate was dissolved in $100 \mu \mathrm{L}$ dimethyl sulfoxide (DMSO). The absorbance (OD) was measured at $490 \mathrm{~nm}$. The proliferation ratio was calculated by the following formula: proliferation ratio $(\%)=\left(\right.$ average $\mathrm{OD}_{\text {treatment group }} /$ average $\mathrm{OD}_{\text {control group }}-$ 1) $\times 100 \%$.

2.5. Cell Cycle and Apoptosis Assay. Cells were incubated in 6-well plates for $48 \mathrm{~h}$ treatment. Then cells were digested and washed. Cell cycle and apoptosis analysis were measured with flow cytometer (BD, Franklin, NJ, USA) according to the instructions of the Cycletest Plus DNA assay kit and Annexin V-FITC/PI apoptosis detection kit, respectively. The percentages of cells in G0/G1 phase, $S$ phase, and G2/M phase were evaluated by the ModFit software (BD, Franklin, NJ, USA). The percentages of early stage and late stage apoptosis were evaluated with CellQuest software (BD, Franklin, NJ, 
USA). Total apoptosis rate was equal to early stage apoptosis plus late stage apoptosis.

2.6. RNA Isolation and Real-Time PCR. Cells at a density of $4 \times 10^{5} /$ well were plated in 6 -well plates for $48 \mathrm{~h}$ treatment. The total RNA was extracted using Trizol reagent, measured by spectrometry at an OD260/280, and reverse transcribed into cDNA in a total volume of $20 \mu \mathrm{L}$ with PrimeScript RT Master Mix. All of the RT-PCR reactions were performed with a CFX96 real-time PCR system (Bio-Rad Laboratories, Hercules, CA) using SYBR Green chemistry (Bio-Rad Laboratories). GAPDH was selected as the control. The primer sequences were as follows: GAPDH, sense: $5^{\prime}$-AGG TTG TCT CCT GCG ACT TCA-3 ${ }^{\prime}$ and antisense: $5^{\prime}$-GGG TGG TCC AGG GTT TCT TAC T-3'; Plzf, sense: $5^{\prime}$-CAC ACA GGC AGA CCC ATA CT- $3^{\prime}$ and antisense: $5^{\prime}$-TTT GTG GCT CTT GAG TGT GC-3'; OCT-4, sense: $5^{\prime}$-CTT GCT GCA GAA GTG GGT GGA GGA A-3' and antisense: $5^{\prime}$-CTG CAG TGT GGG TTT CGG GCA- $3^{\prime}[25,26]$. The reactions were performed at $94^{\circ} \mathrm{C}$ for $3 \mathrm{~min}$ followed by 40 cycles at $94^{\circ} \mathrm{C}$ for $30 \mathrm{~s}, 55^{\circ} \mathrm{C}$ for $30 \mathrm{~s}$, and $72^{\circ} \mathrm{C}$ for $30 \mathrm{~s}$. The final extension was carried out for $5 \mathrm{~min}$ at $72^{\circ} \mathrm{C}$. A melting curve analysis was performed to confirm the products. The relative abundances of the target mRNAs were calculated using the $2^{-\Delta \Delta \mathrm{Ct}}$ method. The data were expressed as the percentage of control (100\%).

2.7. Protein Extraction and Western Blot Analysis. Cells were seeded in $60 \mathrm{~mm}$ dishes at a density of $1 \times 10^{6} /$ well for $48 \mathrm{~h}$ treatment. The cells were harvested, washed three times with precooled PBS, and treated with cell lysis buffer for western blot analysis. After centrifugation at $12.000 \mathrm{~g}$ at $4^{\circ} \mathrm{C}$ for $20 \mathrm{~min}$, the supernatants were collected and stored at $-80^{\circ} \mathrm{C}$ until analysis.

The concentrations of protein were measured by the BioRad Bradford assay (Bio-Rad Laboratories, Hercules, CA). The proteins were normalized to $50 \mu \mathrm{g} /$ lane, separated by $12 \%$ sodium dodecyl sulfate polyacrylamide gel electrophoresis (SDS-PAGE), and subsequently transferred to nitrocellulose membranes. After treatment with blocking solution (5\% skim milk powder in Tris-buffered saline) at $37^{\circ} \mathrm{C}$ for $1 \mathrm{~h}$, the membranes were incubated overnight with the primary antibodies rabbit monoclonal anti-pAKT (1:5000), rabbit polyclonal anti-Plzf $(1: 500)$, rabbit polyclonal anti-Oct-4 $(1: 400)$, or mouse monoclonal anti- $\beta$-actin $(1: 5000)$ at $4^{\circ} \mathrm{C}$. After washing with TBS three times, the membranes were incubated with HRP-conjugated secondary antibodies (1: $5000)$ at $37^{\circ} \mathrm{C}$ for $1 \mathrm{~h}$ and examined using enhanced chemiluminescence. The relative protein levels in each sample were normalized to the levels of $\beta$-actin to standardize the variations in loading. Densitometric analyses of the scanned immunoblotting images were performed using a Quantity One image system. The data are expressed as a percentage of the control (100\%).

2.8. Statistical Analysis. Data were analyzed using a SPSS 16.0 statistical package. All results were expressed as mean \pm standard deviation (S.D.). One-way analysis of variance

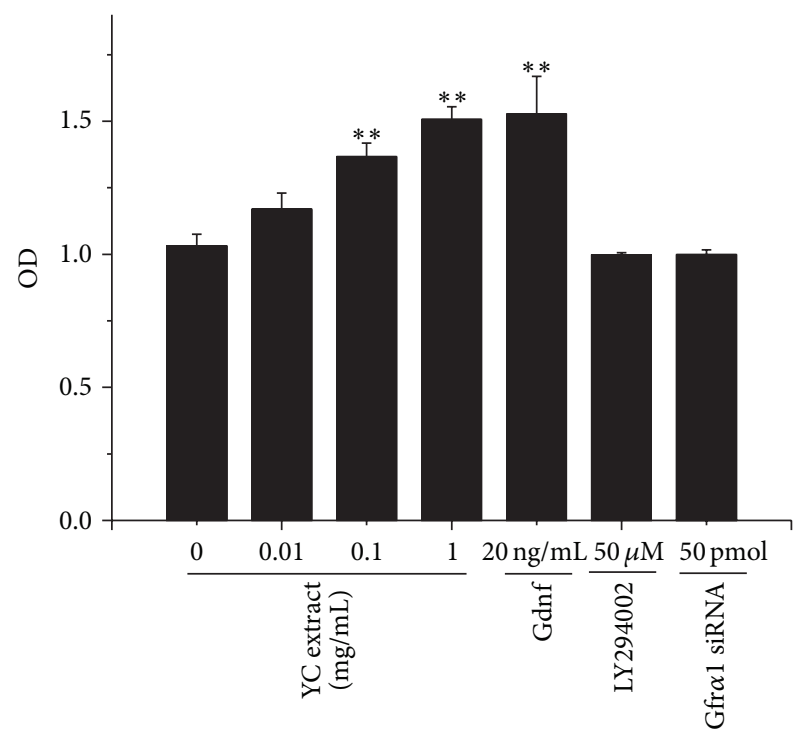

FIGURE 1: Effects of YC extract on proliferation of GC-1 spg cells. Cells were treated with $0,0.01,0.1$, and $1 \mathrm{mg} / \mathrm{mL} \mathrm{YC}$ extract, $20 \mathrm{ng} / \mathrm{mL}$ Gdnf, $50 \mu \mathrm{M}$ LY294002, and $50 \mathrm{pmol}$ Gfr $\alpha 1$ siRNA, respectively. ${ }^{* *}$ Significantly different from control at $P<0.01, n=5$.

(ANOVA) was used to analyze the difference between groups, followed by Dunnett's $t$-test. $P<0.05$ was considered as statistically significant.

\section{Results}

3.1. Effects of YC Extract on Proliferation of GC-1 Spg Cells. The effects of YC extract on cell proliferation are shown in Figure 1. Gdnf, responsible for proliferation of SSCs, was used as positive control. In the presence of $0.01,0.1$, and $1 \mathrm{mg} / \mathrm{mL}$ YC extract for $48 \mathrm{~h}$, OD values increased in a dose dependent manner. The proliferation rates of GC-1 spg cells increased by $13.38 \%, 32.47 \%$, and $46.04 \%$, respectively. In the presence of $20 \mathrm{ng} / \mathrm{mL}$ Gdnf for $48 \mathrm{~h}$, the proliferation rates of GC-1 spg cells significantly increased by $47.98 \%$. There are no evident changes observed with the treatment of $50 \mu \mathrm{M}$ LY294002 or 50 pmol Gfr $\alpha 1$ siRNA.

3.2. Effects of YC Extract on Cell Cycle of GC-1 Spg Cells. Results of cell cycle assay of GC-1 spg cells are shown in Figure 2. The percentage of $\mathrm{S}$ phase in control group was $30.52 \%$ (Figure $2(\mathrm{a})$ ), and after $48 \mathrm{~h}$ treatment of different doses of YC extract, the percentage of S phase evidently rose to $37.45 \%, 41.47 \%$, and $46.30 \%$, respectively (Figures $2(\mathrm{~b})$, 2(c), and 2(d)). A decline of percentage of G0/G1 phase was also observed. These data suggested that YC extract could advance the cell cycle from the G1 phase to the $S$ phase and promote proliferation of spg cells.

3.3. Effects of YC Extract on Apoptosis of GC-1 Spg Cells. As shown in Figure 3, total apoptosis rate was equal to early stage apoptosis (LR) plus late stage apoptosis (UR). The apoptosis rates are $9.68(\mathrm{a}), 8.95(\mathrm{~b}), 5.31$ (c), and $2.38(\mathrm{~d})$, respectively. $0.01 \mathrm{mg} / \mathrm{mL}$ YC extract had no evident effect on apoptosis of 


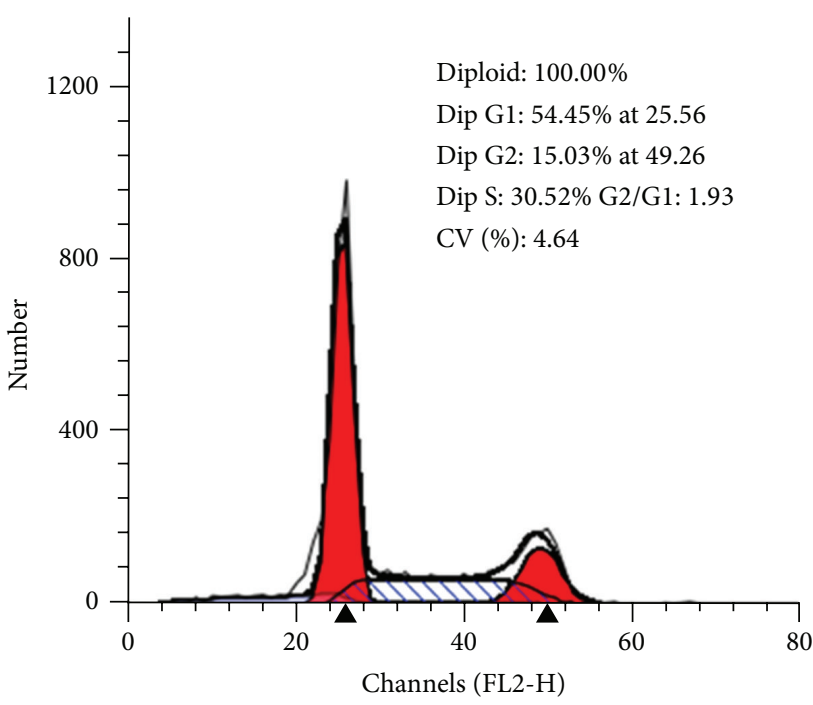

(a)

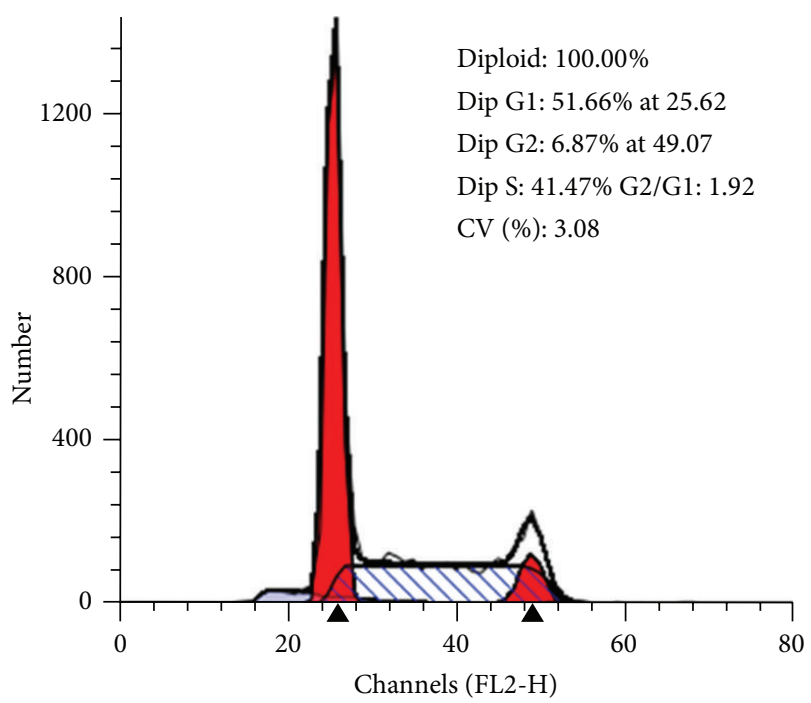

(c)

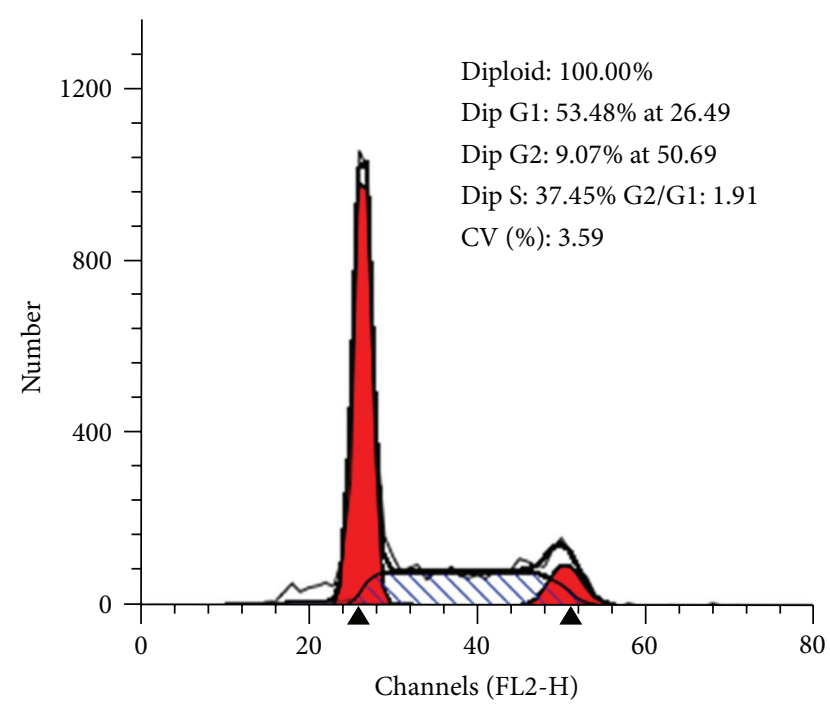

(b)

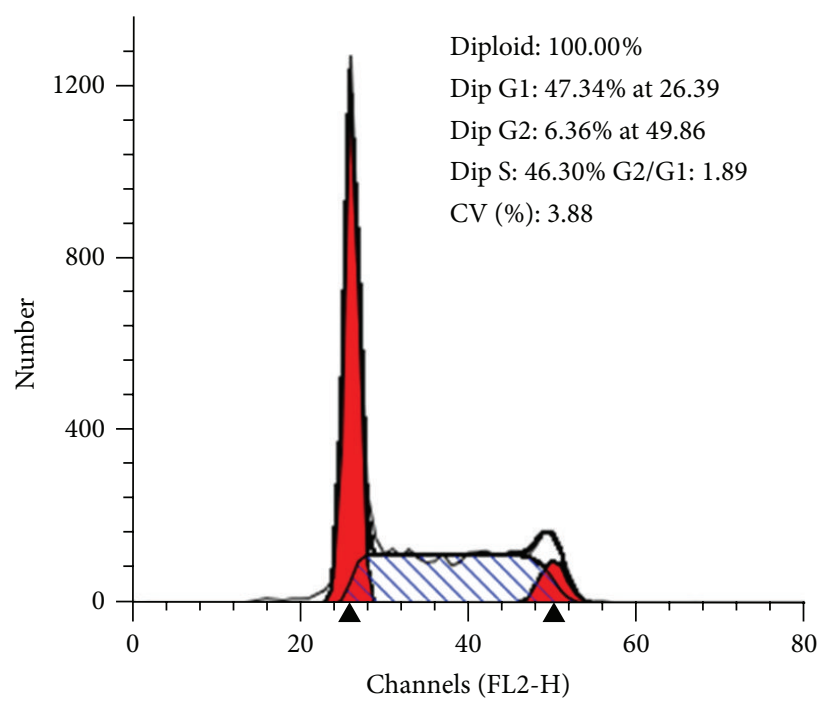

(d)

FIGURE 2: Effects of YC extract on cell cycle of GC-1 spg cells. Cells were treated with 0 (a), 0.01 (b), 0.1 (c), and 1 (d) mg/mL YC extract for $48 \mathrm{~h}$, respectively. The analysis was performed in triplicate and representative data was shown.

GC-1 spg cells. However, 0.1 and $1 \mathrm{mg} / \mathrm{mL}$ YC extract notably inhibited cell apoptosis.

\subsection{Effects of the YC Extract on the Expression of Oct-4 and Plzf} $m R N A s$ and Proteins. Oct-4 and Plzf were chosen as stem cell markers to confirm the undifferentiated status of GC-1 spg cells. Figures 4(a) and 4(b) showed that the expression of Oct- 4 and Plzf mRNAs increased significantly by exposure of $0.1,1 \mathrm{mg} / \mathrm{mL}$ YC extract and $20 \mathrm{ng} / \mathrm{mL}$ Gdnf. Accordingly, Figure 4(c) showed that the expression of Oct-4 and Plzf proteins increased evidently at the same condition. The result suggested that YC extract could promote self-renewal of GC-1 spg cells.

3.5. Gfro1 Knockdown or PI3K Inhibition Blocks YC Extract Induced Proliferation of GC-1 Spg Cells. To investigate the mechanism of YC extract induced proliferation of GC-1 spg cells, Gfr $\alpha 1$ knockdown and PI3K inhibition were performed. As shown in Figure 5, YC extract significantly stimulated the cell proliferation. However, both Gfr $\alpha 1$ siRNA and LY294002, an inhibitor of PI3K, could evidently abrogate the stimulative effect of YC extract.

3.6. Gfro1 Knockdown or PI3K Inhibition Blocks YC Extract Induced Upregulation of Oct-4 and Plzf Expression. The results of Figure 6 showed that both Gfr $\alpha 1$ siRNA and LY294002 could abolish the upregulation of Oct-4 and Plzf expression at levels of mRNA and protein induced by $\mathrm{YC}$ extract. Meanwhile, upregulation of $\mathrm{pAKT}$ protein expression induced by YC extract, evidence for PI3K pathway activation, was also suppressed by Gfr $\alpha 1$ siRNA and LY294002. Combined with the results above, it could be inferred that 


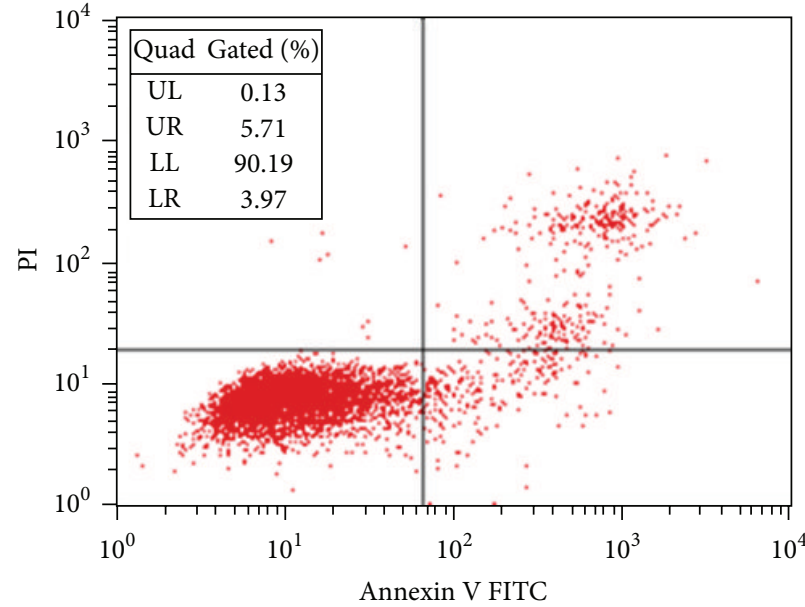

(a)

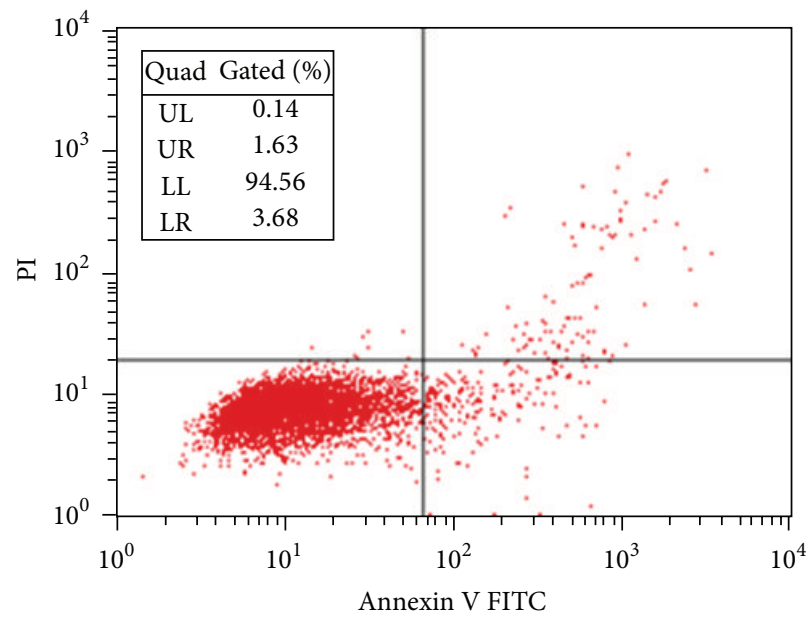

(c)

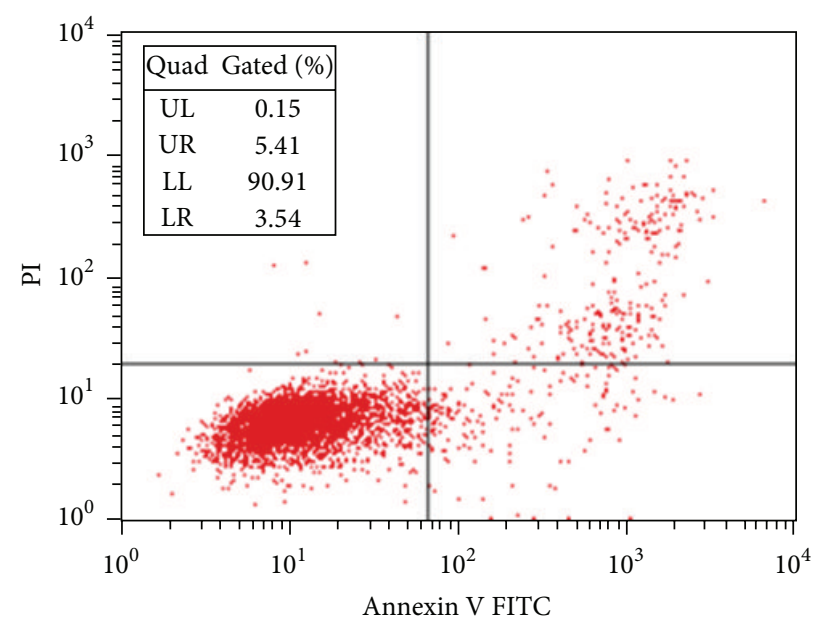

(b)

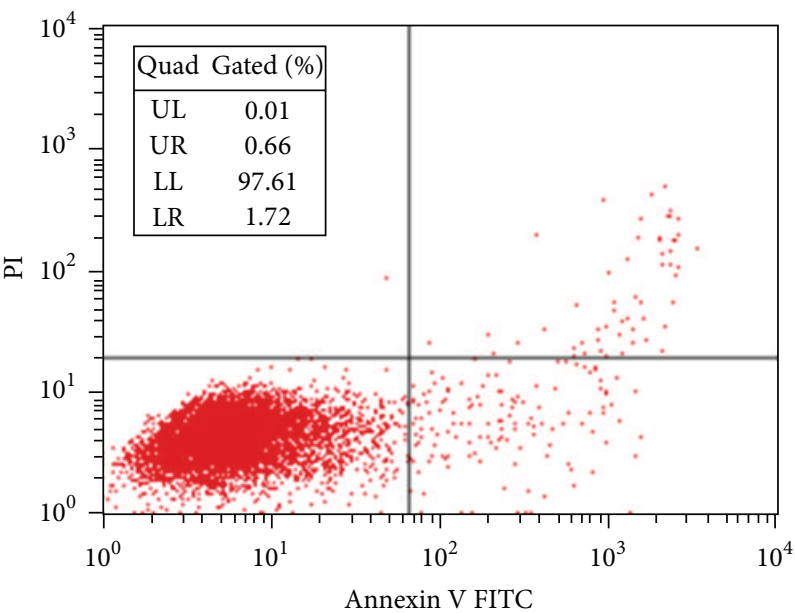

(d)

FIGURE 3: Effects of YC extract on apoptosis of GC-1 spg cells. Cells were treated with 0 (a), 0.01 (b), 0.1 (c), and 1 (d) mg/mL YC extract for $48 \mathrm{~h}$, respectively. Annexin $\mathrm{V}^{+} / \mathrm{PI}^{-}$population (LR in diagram) indicated early apoptosis, and annexin $\mathrm{V}^{+} / \mathrm{PI}^{+}$population (UR in diagram) indicated late apoptosis. The analysis was performed in triplicate and representative data was shown.

Gfr $\alpha 1$ and PI3K played crucial roles in the promotion of selfrenewal induced by YC extract.

\section{Discussion}

YC extract has been used for male infertility therapy in clinic for years, but the mechanisms still remain unclear. Our results suggested that $\mathrm{YC}$ extract could stimulate self-renewal of SSCs and protect SSCs from apoptosis, thus improving spermatogenesis.

Oct- 4 is considered to be the master transcription factor responsible for preserving the pluripotency and self-renewal of stem cells $[11,25]$. It is downregulated during differentiation with loss of pluripotency [27-29] and generally accepted as a stem cell marker. Plzf has also drawn wide attention due to its role of regulating differentiation. Plzf is claimed to be essential for maintaining pluripotent properties and self-renewal as its expression is confined to stem cells and early progenitor cells $[12,30,31]$. While Plzf is expressed at high level in undifferentiated pluripotent stem cells, its expression declined when differentiation started. Our results showed that $48 \mathrm{~h}$ treatment of YC extract not only promoted the proliferation of GC-1 spg cells but also promoted selfrenewal of cells proved by enhanced expression of Oct- 4 and Plzf mRNAs and proteins, which were quite similar to the effect of Gdnf treatment (Figures 1 and 4). As a matter of course, we deduced that YC extract probably functioned in the similar ways as Gdnf.

Gdnf, secreted by Sertoli cells, is so far the only known paracrine factor specifically responsible for the maintenance and self-renewal of SSCs in vivo $[13,14]$. Lin et al. reported that Gdnf is a member of the transforming growth factor beta (TGF- $\beta$ ) superfamily [32]. Gdnf signals through a multicomponent receptor complex are composed of the Ret receptor tyrosine kinase and Gfr $\alpha 1[33,34]$. Gdnf can trigger various downstream signal pathways to promote cell survival and self-renewal via GPI-linked protein Gfr $\alpha 1$ [35, 36]. Based on the comparable effects of YC extract and 


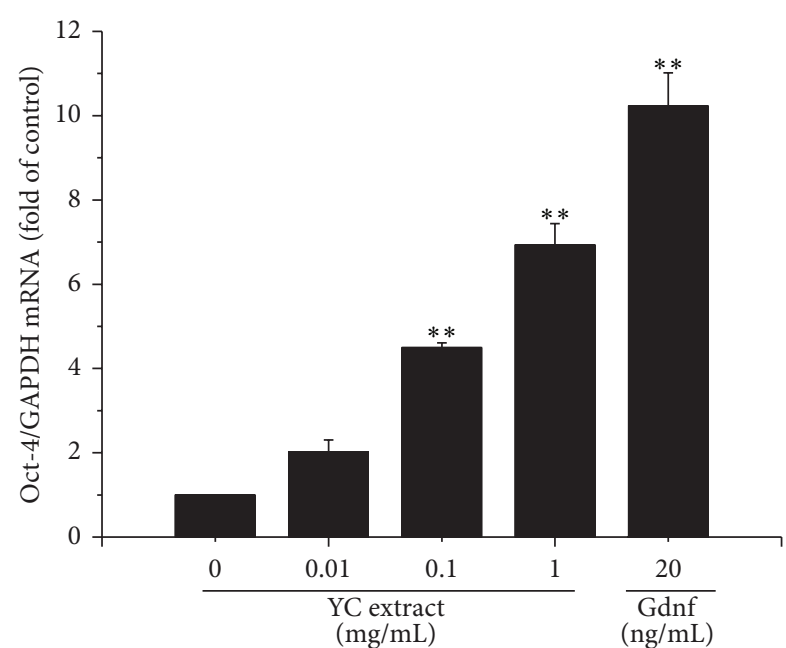

(a)

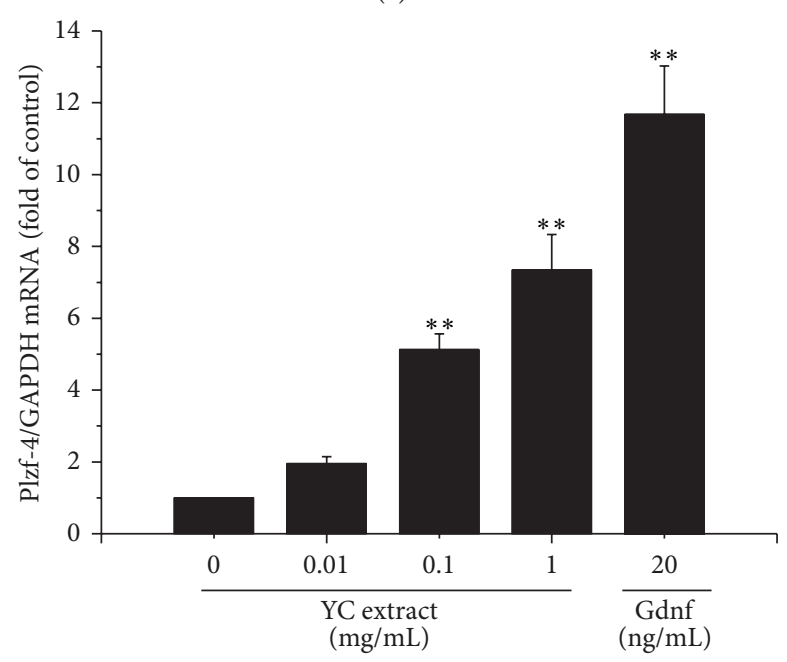

(b)
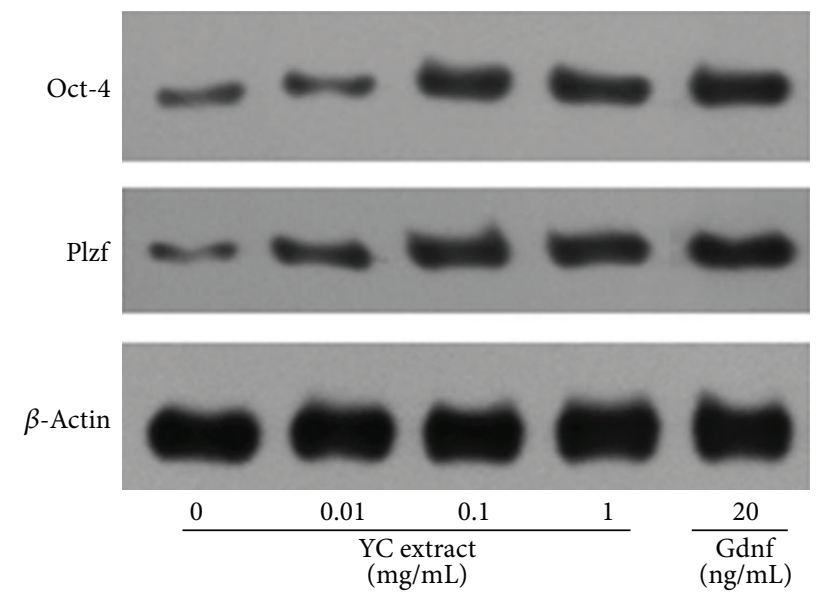

(c)

FIGURE 4: Effects of the YC extract on the expression of Oct-4 and Plzf mRNAs and proteins in GC-1 spg cells. GC-1 spg cells were treated with $0.01,0.1$, and $1 \mathrm{mg} / \mathrm{mL}$ YC extract or $20 \mathrm{ng} / \mathrm{mL}$ Gdnf for $48 \mathrm{~h}$. Expression of mRNAs was detected by real-time PCR. Expression of proteins was detected by western blot. The data are expressed as the percentage of the control (100\%). ${ }^{* *}$ Significantly different from control at $P<0.01$. The analysis was performed in triplicate and representative bands were shown.

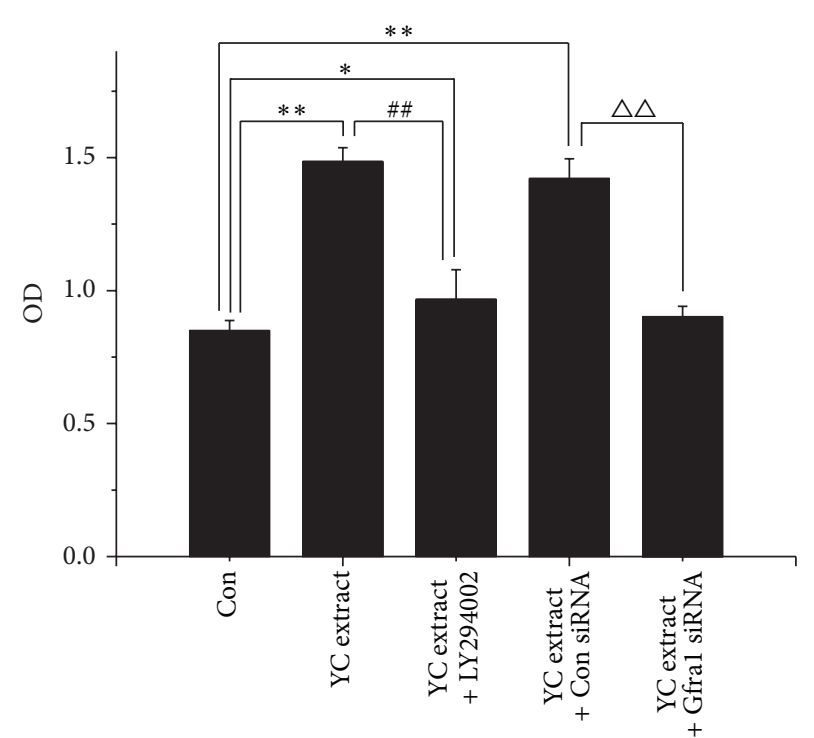

FIGURE 5: Gfr $\alpha 1$ knockdown or PI3K inhibition blocks YC extract induced proliferation of GC-1 spg cells. GC-1 cells were exposed to control blank, $1 \mathrm{mg} / \mathrm{mL}$ YC extract, $1 \mathrm{mg} / \mathrm{mL}$ YC extract with $50 \mu \mathrm{M}$ LY294002, and $1 \mathrm{mg} / \mathrm{mL}$ YC extract with or without $50 \mathrm{pmol}$ Gfr $\alpha 1$ siRNA. ${ }^{*} P<0.05 ;{ }^{* *} P<0.01$ compared with control group; ${ }^{\# \#} P<$ 0.01 compared with YC extract group; ${ }^{\triangle} P<0.01$ compared with YC extract and control siRNA group, $n=5$.

Gdnf, we speculated that Gfr $\alpha 1$ also plays a key role in YC extract's biological effects. To confirm our hypothesis, we used siRNA to knockdown Gfr $\alpha 1$ expression in current research. Figure 5 showed that Gfr $\alpha 1$ knockdown almost entirely abolished the proliferous effect of GC-1 cells induced by YC extract. Corresponding with this, Gfr $\alpha 1$ knockdown also abrogated the elevated expression of Oct- 4 and Plzf mRNAs and proteins induced by YC extract (Figure 6). On the basis of these results, we inferred that YC extract exerts biological effects partly via Gfr $\alpha 1$.

To further investigate the mechanism of YC extract, we treated GC-1 cells with $50 \mu \mathrm{M}$ LY294002 to inhibit PI3K pathway before the treatment of YC extract. PI3K pathway has been demonstrated to play a central role in the Gdnf induced self-renewal of SSCs $[37,38]$. The binding of Gdnf to Gfr $\alpha 1$ triggers phosphorylation of SRC-kinase family proteins followed by activation of PI3K/AKT pathway and eventually leads to self-renewal of SSCs via expression of $N-m y c$ gene [15, 16]. As has been stated, like Gdnf, YC extract also induces selfrenewal via Gfr $\alpha 1$, and activation of PI3K pathway is most likely very crucial in YC extract's effects. As expected, pAKT protein expression increased evidently after treatment of YC extract standing for PI3K pathway activation (Figure 6). PI3K pathway inhibition evidently removed the proliferous effect of GC-1 spg cells induced by YC extract which was shown in Figure 5. Consistent with this, the upregulated Oct- 4 and Plzf mRNAs and proteins also dropped down by LY294002 treatment (Figure 6).

In summary, YC extract could improve spermatogenesis by means of promoting self-renewal of SSCs and protecting SSCs from apoptosis, which were verified by cell proliferation and upregulation of OCT-4 and Plzf expression after the 


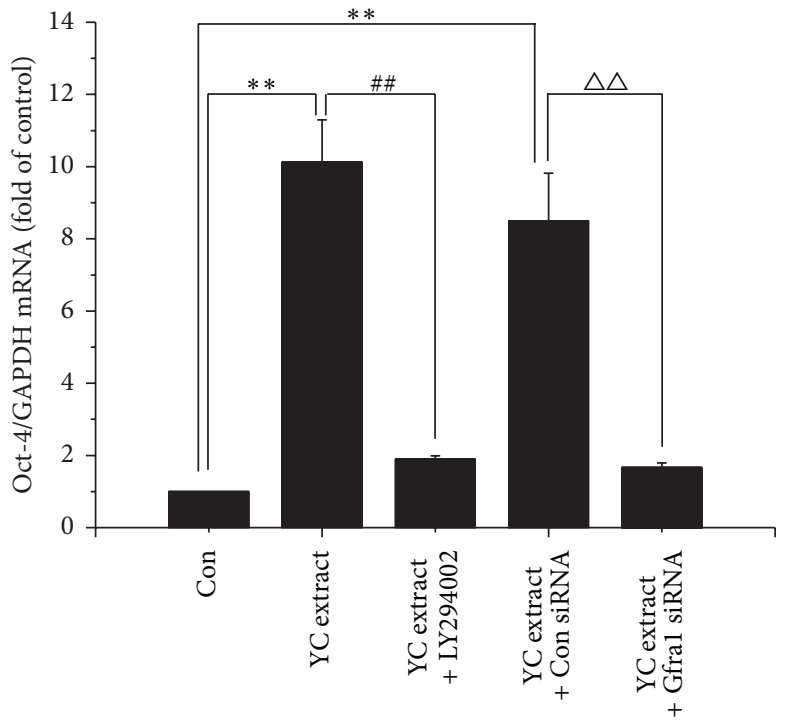

(a)

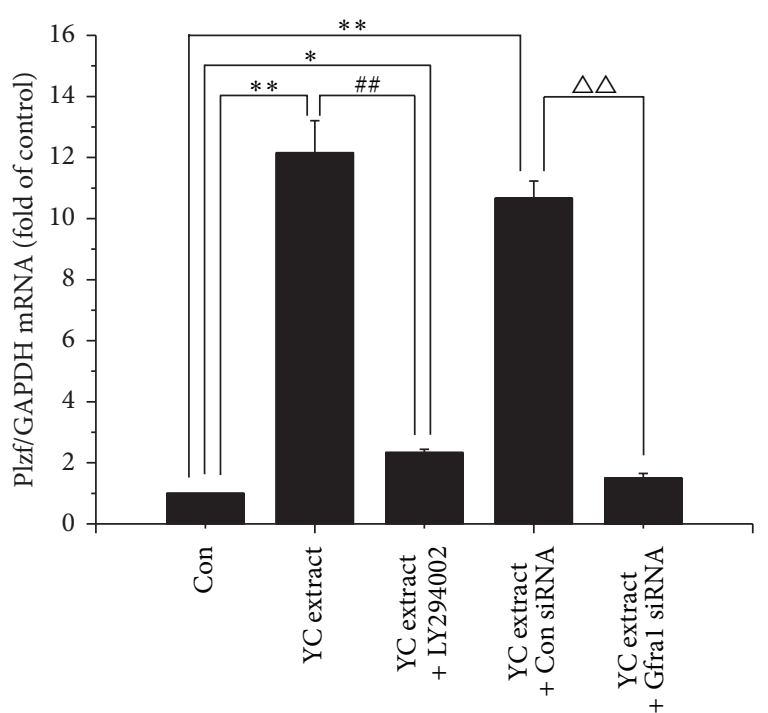

(b)

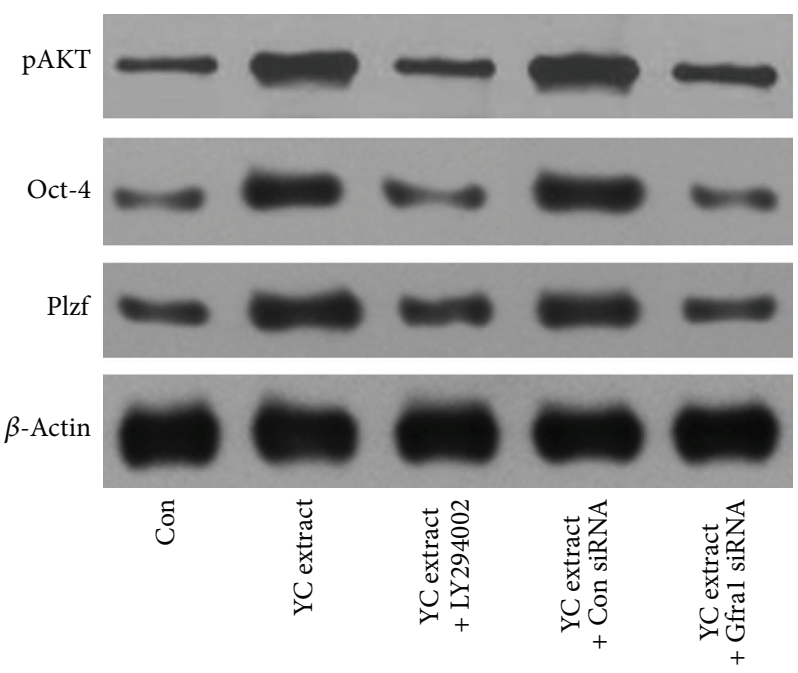

(c)

FIGURE 6: Gfr $\alpha 1$ knockdown or PI3 K inhibition blocks YC extract induced upregulation of Oct- 4 and Plzf expression. GC-1 cells were exposed to control blank, $1 \mathrm{mg} / \mathrm{mL}$ YC extract, $1 \mathrm{mg} / \mathrm{mL}$ YC extract with $50 \mu \mathrm{M}$ LY294002, and $1 \mathrm{mg} / \mathrm{mL}$ YC extract with or without 50 pmol Gfr $\alpha 1$ siRNA. ${ }^{*} P<0.05$; $^{* *} P<0.01$ compared with control group; ${ }^{\# \#} P<0.01$ compared with YC extract group; ${ }^{\triangle \triangle} P<0.01$ compared with YC extract and control siRNA group. The analysis was performed in triplicate and representative bands were shown.

treatment of YC extract. To explore possible mechanism, we performed Gfr $\alpha 1$ knockdown and PI3K inhibition before application of YC extract. The results showed that both Gfr $\alpha 1$ knockdown and PI3K inhibition were able to evidently remove the cell proliferation and upregulation of OCT-4 and Plzf expression induced by $\mathrm{YC}$ extract. Therefore, we concluded that, partly via Gfr $\alpha 1$, YC extract could trigger the activation of PI3K pathway and finally lead to selfrenewal of SSCs. However, as YC extract is composed of multiple components, further studies are needed to identify the primary effective component.

\section{Conflict of Interests}

There is no conflict of interests regarding the publication of this paper.

\section{Acknowledgments}

This work was supported by the Chinese National Natural Science Foundation (no. 81273760, no. 81302969) and a Postgraduate Innovation Program of the Jiangsu Province Education Department (no. CXLX13_583). The authors thank the State Key Laboratory of Reproductive Medicine, the Clinical Center of Reproductive Medicine, and the Nanjing Medical University for providing laboratory and technological assistance.

\section{References}

[1] B. D. Anawalt, "Approach to male infertility and induction of spermatogenesis," The Journal of Clinical Endocrinology \& Metabolism, vol. 98, pp. 3532-3542, 2013. 
[2] C. A. Holden, R. I. McLachlan, M. Pitts et al., "Men in Australia Telephone Survey (MATeS): a national survey of the reproductive health and concerns of middle-aged and older Australian men," The Lancet, vol. 366, no. 9481, pp. 218-224, 2005.

[3] T. J. Walsh, R. R. Pera, and P. J. Turek, "The genetics of male infertility," Seminars in Reproductive Medicine, vol. 27, no. 2, pp. 124-136, 2009.

[4] K. L. O’Flynn O’Brien, A. C. Varghese, and A. Agarwal, “The genetic causes of male factor infertility: a review," Fertility and Sterility, vol. 93, no. 1, pp. 1-12, 2010.

[5] E. Vicari, A. E. Calogero, R. A. Condorelli, L. O. Vicari, and S. La Vignera, "Male accessory gland infection frequency in infertile patients with chronic microbial prostatitis and irritable bowel syndrome," International Journal of Andrology, vol. 35, no. 2, pp. 183-189, 2012.

[6] S. R. Singh, O. Burnicka-Turek, C. Chauhan, and S. X. Hou, "Spermatogonial stem cells, infertility and testicular cancer," Journal of Cellular and Molecular Medicine, vol. 15, no. 3, pp. 468-483, 2011.

[7] N. Schultz, F. K. Hamra, and D. L. Garbers, "A multitude of genes expressed solely in meiotic or postmeiotic spermatogenic cells offers a myriad of contraceptive targets," Proceedings of the National Academy of Sciences of the United States of America, vol. 100, no. 21, pp. 12201-12206, 2003.

[8] K. Caires, J. Broady, and D. McLean, "Maintaining the male germline: regulation of spermatogonial stem cells," Journal of Endocrinology, vol. 205, no. 2, pp. 133-145, 2010.

[9] K. C. Caires, J. de Avila, and D. J. McLean, "Endocrine regulation of spermatogonial stem cells in the seminiferous epithelium of adult mice," BioResearch Open Access, vol. 1, pp. 222-230, 2012.

[10] Z. He, M. Kokkinaki, J. Jiang, I. Dobrinski, and M. Dym, "Isolation, characterization, and culture of human spermatogonia," Biology of Reproduction, vol. 82, no. 2, pp. 363-372, 2010.

[11] D. Bhartiya, "Are mesenchymal cells indeed pluripotent stem cells or just stromal cells? OCT-4 and VSELs biology has led to better understanding," Stem Cells International, vol. 2013, Article ID 547501, 6 pages, 2013.

[12] G. M. Costa, G. F. Avelar, J. V. Rezende-Neto et al., "Spermatogonial stem cell markers and niche in equids," PLoS ONE, vol. 7, Article ID e44091, 2012.

[13] M.-C. Hofmann, L. Braydich-Stolle, and M. Dym, "Isolation of male germ-line stem cells; Influence of GDNF," Developmental Biology, vol. 279, no. 1, pp. 114-124, 2005.

[14] H. Kubota, M. R. Avarbock, and R. L. Brinster, "Growth factors essential for self-renewal and expansion of mouse spermatogonial stem cells," Proceedings of the National Academy of Sciences of the United States of America, vol. 101, no. 47, pp. 16489-16494, 2004.

[15] M. J. Goertz, Z. Wu, T. D. Gallardo, F. K. Hamra, and D. H. Castrillon, "Foxol is required in mouse spermatogonial stem cells for their maintenance and the initiation of spermatogenesis," Journal of Clinical Investigation, vol. 121, no. 9, pp. 3456-3466, 2011.

[16] J. M. Oatley, M. R. Avarbock, and R. L. Brinster, "Glial cell linederived neurotrophic factor regulation of genes essential for self-renewal of mouse spermatogonial stem cells is dependent on Src family kinase signaling," Journal of Biological Chemistry, vol. 282, no. 35, pp. 25842-25851, 2007.
[17] R. Brehm and K. Steger, "Regulation of sertoli cell and germ cell differentation," Advances in Anatomy Embryology and Cell Biology, vol. 181, pp. 1-93, 2005.

[18] J. M. Oatley, M. J. Oatley, M. R. Avarbock, J. W. Tobias, and R. L. Brinster, "Colony stimulating factor 1 is an extrinsic stimulator of mouse spermatogonial stem cell self-renewal," Development, vol. 136, no. 7, pp. 1191-1199, 2009.

[19] M.-C. Hofmann, "Gdnf signaling pathways within the mammalian spermatogonial stem cell niche," Molecular and Cellular Endocrinology, vol. 288, no. 1-2, pp. 95-103, 2008.

[20] B. Jin, Y. Huang, X. Xia, X. Wang, X. Yang, and Z. Zhou, "Effect of Yangjing capsule and Xinxibao on sperm DNA integrity of patients with male infertility," Chinese Journal of Andrology, vol. 20, no. 12, pp. 45-49, 2006.

[21] D. Sun, Y. Cui, B. Jin et al., "Effects of the yangjing capsule extract on steroidogenesis and apoptosis in mouse leydig cells," Evidence-Based Complementary and Alternative Medicine, vol. 2012, Article ID 985457, 10 pages, 2012.

[22] B. Jin, Y. Huang, X. Yang et al., "Clinical observation on treatment of oligospermatism with Yangjing Capsule," Journal of Nanjing University of Traditional Chinese Medicine, vol. 22, pp. 286-289, 2006.

[23] S.-T. Kao, C.-C. Yeh, C.-C. Hsieh et al., "The Chinese medicine $\mathrm{Bu}$-Zhong-Yi-Qi-Tang inhibited proliferation of hepatoma cell lines by inducing apoptosis via G0/G1 arrest," Life Sciences, vol. 69, no. 13, pp. 1485-1496, 2001.

[24] Z. He, J. Jiang, M.-C. Hofmann, and M. Dym, "Gfral silencing in mouse spermatogonial stem cells results in their differentiation via the inactivation of RET tyrosine kinase," Biology of Reproduction, vol. 77, no. 4, pp. 723-733, 2007.

[25] D. Bhartiya, S. Kasiviswanathan, S. K. Unni et al., "Newer insights into premeiotic development of germ cells in adult human testis using Oct-4 as a stem cell marker," Journal of Histochemistry and Cytochemistry, vol. 58, no. 12, pp. 1093-1106, 2010.

[26] M. Cheung, J. Pei, Y. Pei, S. C. Jhanwar, H. I. Pass, and J. R. Testa, "The promyelocytic leukemia zinc-finger gene, PLZF, is frequently downregulated in malignant mesothelioma cells and contributes to cell survival," Oncogene, vol. 29, no. 11, pp. 1633$1640,2010$.

[27] P. A. Campbell, C. Perez-Iratxeta, M. A. Andrade-Navarro, and M. A. Rudnicki, "Oct4 targets regulatory nodes to modulate stem cell function," PLoS ONE, vol. 2, no. 6, article e553, 2007.

[28] D. C. Hay, L. Sutherland, J. Clark, and T. Burdon, "Oct-4 knockdown induces similar patterns of endoderm and trophoblast differentiation markers in human and mouse embryonic stem cells," Stem Cells, vol. 22, no. 2, pp. 225-235, 2004.

[29] C. J. Lengner, G. G. Welstead, and R. J. Rudolf Jaenisch, "The pluripotency regulator Oct4: a role in somatic stem cells?” Cell Cycle, vol. 7, no. 6, pp. 725-728, 2008.

[30] J. A. Costoya, R. M. Hobbs, M. Barna et al., "Essential role of Plzf in maintenance of spermatogonial stem cells," Nature Genetics, vol. 36, no. 6, pp. 653-659, 2004.

[31] W. Song, H. Zhu, M. Li et al., "Promyelocytic leukaemia zinc finger maintains self-renewal of male germline stem cells (mGSCs) and its expression pattern in dairy goat testis," Cell Proliferation, vol. 46, pp. 457-468, 2013.

[32] L.-F. H. Lin, D. H. Doherty, J. D. Lile, S. Bektesh, and F. Collins, "GDNF: a glial cell line-derived neurotrophic factor for midbrain dopaminergic neurons," Science, vol. 260, no. 5111, pp. 1130-1132, 1993. 
[33] S. Jing, D. Wen, Y. Yu et al., "GDNF-induced activation of the Ret protein tyrosine kinase is mediated by GDNFR- $\alpha$, a novel receptor for GDNF," Cell, vol. 85, no. 7, pp. 1113-1124, 1996.

[34] J. J. S. Treanor, L. Goodman, F. De Sauvage et al., "Characterization of a multicomponent receptor for GDNF," Nature, vol. 382, no. 6586 , pp. 80-83, 1996.

[35] M. Grasso, A. Fuso, L. Dovere et al., "Distribution of GFRA1expressing spermatogonia in adult mouse testis," Reproduction, vol. 143, no. 3, pp. 325-332, 2012.

[36] M. Trupp, R. Scott, S. R. Whittemore, and C. F. Ibáñez, "Retdependent and -independent mechanisms of glial cell linederived neurotrophic factor signaling in neuronal cells," Journal of Biological Chemistry, vol. 274, no. 30, pp. 20885-20894, 1999.

[37] L. Braydich-Stolle, N. Kostereva, M. Dym, and M.-C. Hofmann, "Role of Src family kinases and N-Myc in spermatogonial stem cell proliferation," Developmental Biology, vol. 304, no. 1, pp. 3445, 2007.

[38] J. Lee, M. Kanatsu-Shinohara, K. Inoue et al., "Akt mediates self-renewal division of mouse spermatogonial stem cells," Development, vol. 134, no. 10, pp. 1853-1859, 2007. 


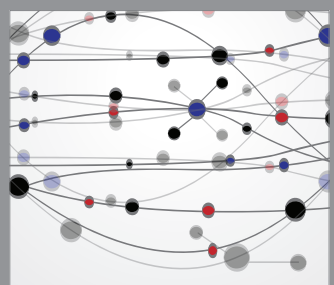

The Scientific World Journal
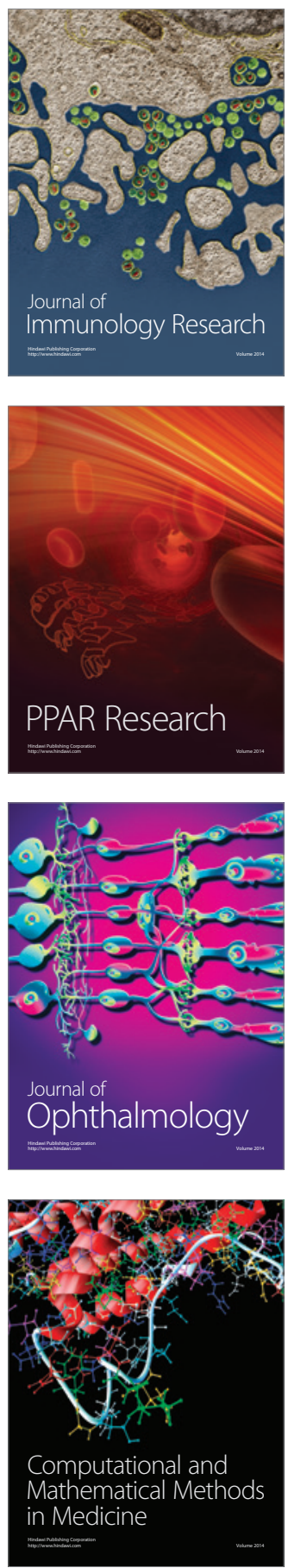

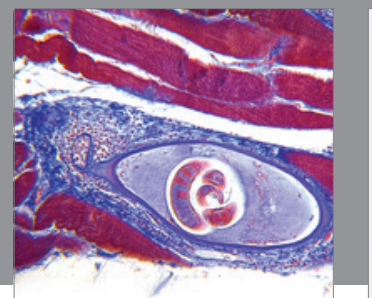

Gastroenterology

Research and Practice
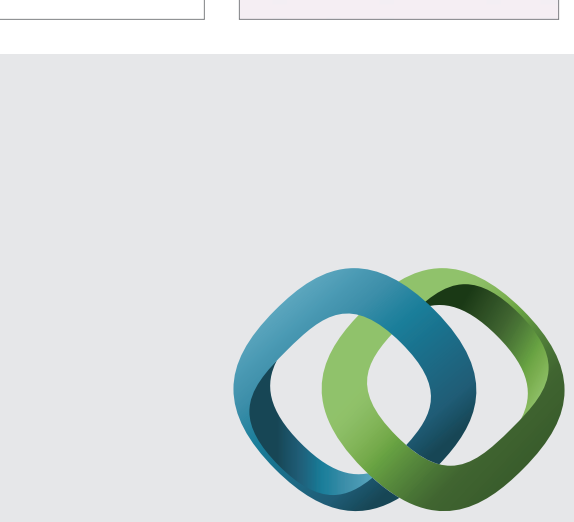

\section{Hindawi}

Submit your manuscripts at

http://www.hindawi.com
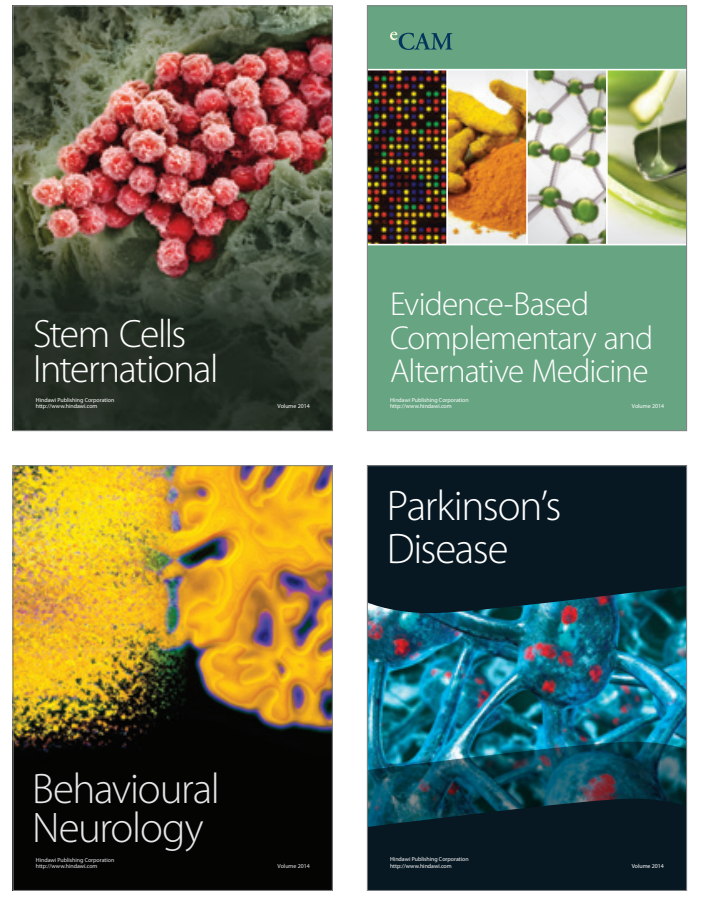
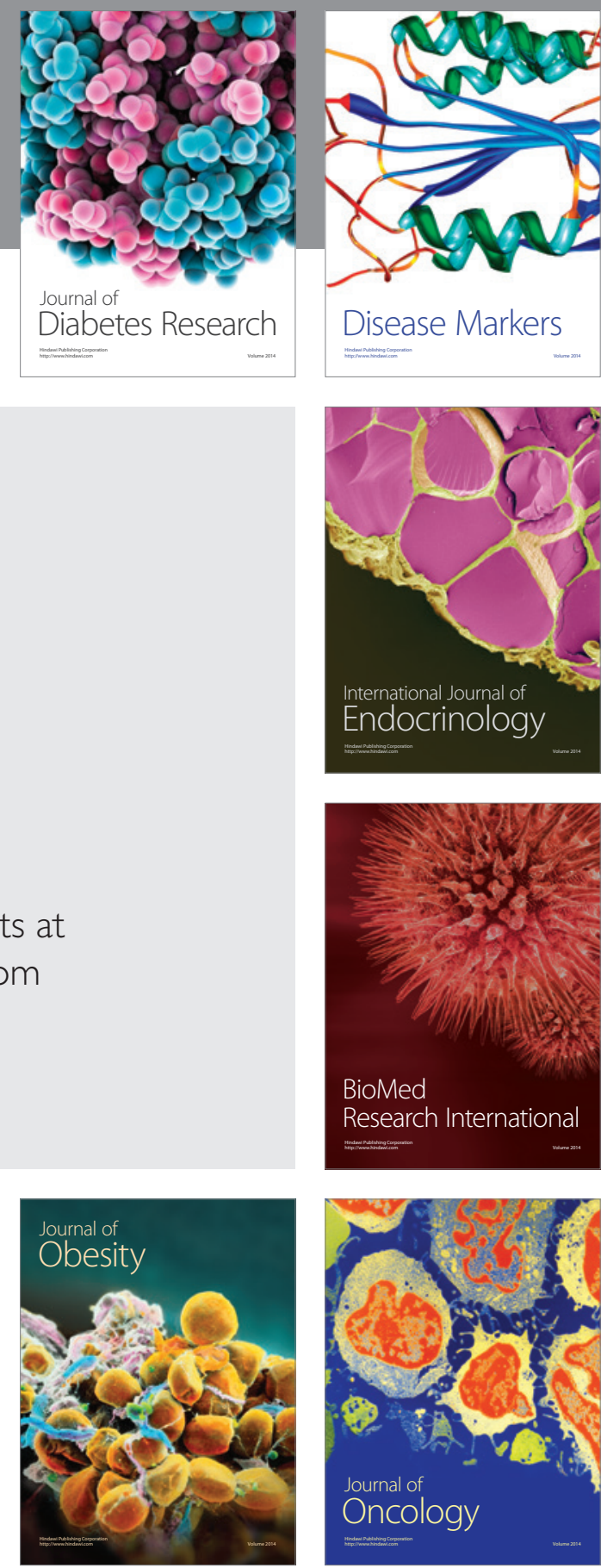

Disease Markers
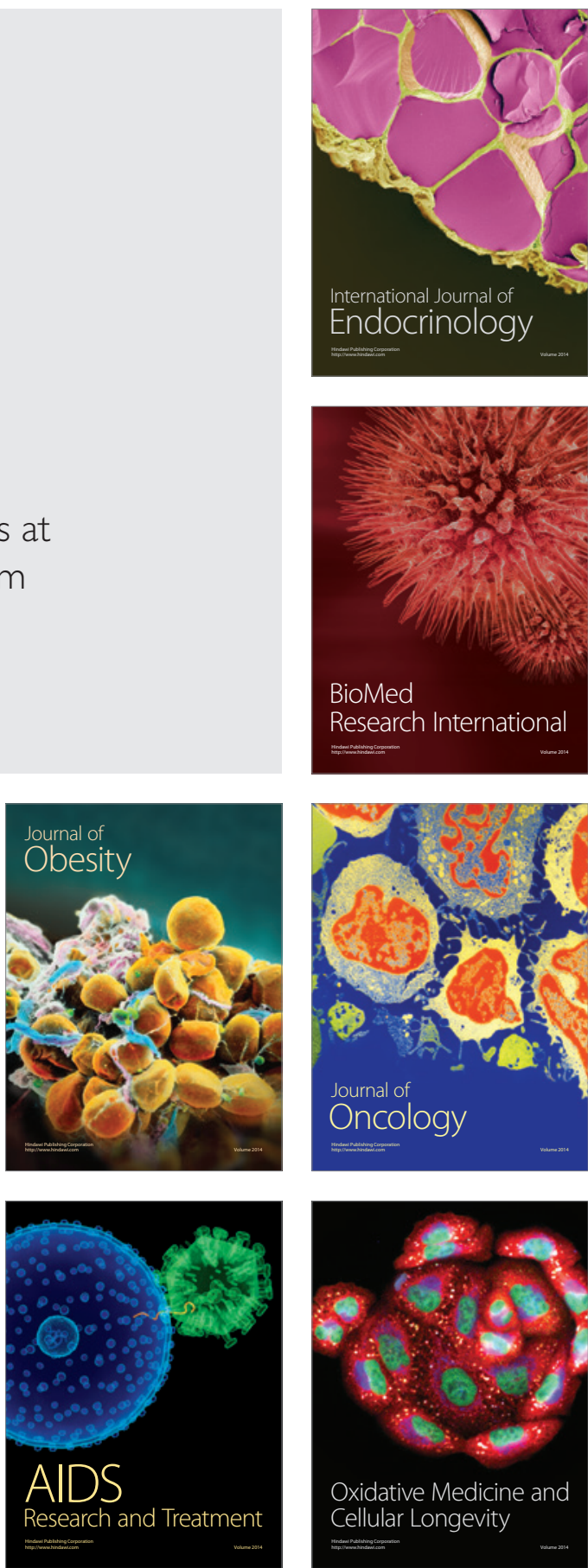